\title{
Gea
}

JURNAL PENDIDIKAN GEOGRAFI

\section{PERAN SISTEM INFORMASI GEOGRAFIS (SIG) DALAM MENINGKATKAN KEMAMPUAN BERPIKIR SPASIAL (SPATIAL THINKING)}

\author{
Iwan Setiawan \\ Departemen Pendidikan Geografi, FPIPS, UPI, email: iwan4671@gmail.com
}

\begin{abstract}
ABSTRAK
SIG merupakan aplikasi yang dikembangkan untuk memecahkan persoalan yang berkaitan dengan permukaan bumi. Namun, dalam perkembangannya SIG sangat diandalkan dalam membantu kegiatan pembelajaran yang terkait dengan aspek spasial. Geografi merupakan mata pelajaran yang fokusnya pada pengembangan berpikir spasial, sehingga SIG menjadi sistem pendukung yang sangat diandalkan. Pemanfaatan SIG dalam mengembangkan berpikir spasial tersebut telah diuji kehandalannya dalam sejumlah penelitian yang menunjukkan adanya kontribusi positif SIG dalam mengembangkan kemampuan berpikir spasial.
\end{abstract}

Kata kunci: Sistem Informasi Geografis, berfikir spasial.

\section{PENDAHULUAN}

Berpikir spasial menjadi penciri penting dalam aktivitas pembelajaran geografi. Kajian terhadap fenomena geografi tidak hanya sekedar menjelaskan keberadaan suatu fenomena dan proses terjadinya fenomena tersebut di permukaan bumi tetapi juga bentuk, ukuran, arah, pola dari fenomena serta keterkaitan dengan fenomena lainnya.

Kemampuan tersebut akan sangat berguna bagi peserta didik ketika akan menentukan atau membuat keputusan dari hal-hal yang sangat sederhana sampai yang kompleks yang terkait dengan ruang atau lokasi. Ketika seseorang akan bepergian, maka dia harus mengetahui tentang jarak dan arah, sehingga dia bisa memprediksi waktu kedatangan dan tidak tersesat.

Berpikir spasial juga diterapkan dalam analisis geografi yang lebih kompleks. Ketika seseorang harus memutuskan untuk mencari lokasi yang paling baik untuk proyek pembuatan real estate, maka di perlu memilikirkan tentang sifat atau karakteristik daerah yang akan dijadikan tempat pembangunannya. Berbagai data yang terkait dengan persyaratan real estate harus digabungkan untuk menghasilkan informasi baru berupa alternatif wilayah yang cocok untuk permukiman.

Banyak persoalan yang terkait dengan permukaan bumi yang bisa dipecahkan oleh mereka yang memiliki cara berpikir spasial. Dengan dukungan teknologi informasi seperti Sistem Informasi Geografis (SIG), maka pekerjaan tersebut menjadi sangat dipermudah. Persoalan lingkungan, perkotaan, banjir, dan berbagai aktivitas untuk menentukan kecenderungan, menentukan lokasi yang paling baik, menentukan pola, dan pemodelan sangat dibantu oleh teknologi SIG. Karena itu, dalam pembelajaran geografi sangat penting untuk ditekankan cara berpikir spasial, tidak hanya sekedar informasi tentang fenomena geosfer. 


\section{HASIL DAN PEMBAHASAN Spatial Thinking}

Menurut National Research Council (2006), berpikir spasial merupakan salah satu bentuk berpikir diantara bentuk berpikir lainnya, seperti verbal, logical, statistical, hipotetical dan seterusnya. Berpikir spasial itu sendiri merupakan sekumpulan kemampuan koginitif, terdiri atas tiga unsur yaitu ruang (space), alat (tools), dan proses pemikiran atau pertimbangan (process of resoning). Pemahaman akan arti dari ruang, misalnya ukurannya, kedekatannya, kontunuitasnya, dapat dijadikan sebagai alat untuk menyusun masalah, menemukan jawaban, dan mengkomunikasikan solusinya. Dengan mengekspresikan hubungan dalam struktur keruangan, misalnya peta, maka kita dapat mempersepsi, mengingat, dan menganalisis sifat-sifat statis dan dinamis objek dan hubungannya dengan objek lainnya. Batasan spatial thinking itu sendiri, menurut National Research Council (2006) adalah:

Spatial thinking is thinking that finds meaning in the shape, size, orientation, location, direction or trajectory, of objects, processes or phenomena, or the relative positions in space of multiple objects, processes or phenomena. Spatial thinking uses the properties of space as a vehicle for structuring problems, for finding answers, and for expressing solutions.

Konsep berpikir spasial (spasial thinking) lebih luas dari kemampuan spasial (spatial ability) walaupun keduanya saling berkaitan. Kemampuan spasial menurut Albert dan Golledge (Lee, 2009) terdiri atas visualisasi spasial, orientasi spasial dan relasi spasial. Visualisasi spasial adalah kemampuan secara mental untuk memanipulasi, merotasi, atau membalikkan stimulus visual yang ditunjukkan secara piktorial. Orientasi spasial melibatkan pemahaman tentang susunan unsur-unsur dalam pola stimulus visual, kecerdasan untuk tetap tidak bingung dengan perubahan orientasi dan kemampuan untuk menentukan hubungan spasial (McGee, 1979 dalam Lee, 2009). Relasi spasial menurut Golledge dan Stimpson (Lee, 2009) melibatkan kemampuan untuk mengenal distribusi dan pola spasial, untuk menghubungkan lokasi, untuk mengasosiasikan dan mengkorelasikan fenomena yang tersebar, untuk memahami dan menggunakan hierarki spasial, untuk membuat regionalisasi, untuk mengarahkan terhadap kerangka acuan di dunia nyata (real-world), untuk mengimajinasikan peta dari deskripsi verbal, untuk menguraikan atau menggambarkan peta, untuk membandingkan peta, untuk menumpangsusunkan peta. Lee (2009) mengemukakan bahwa relasi spasial memiliki keterkaitan yang lebih sesuai dengan aktivitas SIG dibandingkan dengan yang lainnya (spasial visualization dan spasial orientation).

Berpikir spasial menurut Marsh, Golledge dan Batterby (2007) tidak hanya wilayah geografi tetapi juga disiplin lainnya yang menjadikan ruang sebagai suatu faktor yang dapat memberikan penjelasan tentang sifat dan fungsi objek atau gejala, misalnya kimia, fisika, teknik rekayasa, sejarah, seni dan lain-lain. Para ahli geografi, psikologi, serta ahli pendidikan berpendapat bahwa berpikir spasial bersifat universal dan sangat bermanfaat dalam berbagai disiplin akademik dan pemecahan masalah seharihari. Berpikir spasial dapat membantu dalam mengingat, memahami, alasan, dan mengkomunikasikan tentang sifat-sifat dan relasi antara objek dalam ruang.

Berpikir spasial dapat dipelajari dan dapat diajarkan pada berbagai jenjang pendidikan. Pentingnya berpikir spasial disampaikan dalam pendidikan disampaikan oleh National Research Council (2006), yaitu:

1. Berpikir spasial merupakan sekumpulan ketrampilan kognitif. 
2. Berpikir spasial terintegrasi dalam kehidupan sehari-hari. Orang, objek-objek alam, objek buatan manusia menyusun ruang dan interaksi antara orang dan objek harus dipahami dalam konteks lokasi, jarak, arah, bentuk, dan pola.

3. Berpikir spasial sangat kuat dalam memecahkan masalah dengan mengelola, mentransformasi, dan menganalisis data, khususnya data yang kompleks dan bervolume besar dan mengkomunikasikan hasil dari proses tersebut untuk dirinya maupun orang lain.

4. Berpikir spasial menjadi keseharian para ahli dan insinyur, dan menjadi penyokong banyak terobosan ilmu pengetahuan dan teknik.

5. Berpikir spasial merupakan keterampilan yang dapat dan seharusnya dipelajari setiap orang.

6. Berpikir spasial berkembang secara unik bagi setiap orang tergantung pada pengalaman, pendidikan dan kecenderungan seseorang.

7. Berpikir spasial merupakan proses yang rumit, sangat kuat, dam menantang dan system pendukung menyediakan lingkungan yang interaktif yang mana berpikir spasial dapat berlangsung dengan membantu siswa menspasialkan data set, memvisualisasikan pekerjaan dan hasil akhirnya, dan menunjukkan fungsi-fungsi analitis.

8. Dan seterusnya.

Pentingnya berpikir spasial juga dikemukakan oleh Lee (2009) yang menyatakan bahwa berpikir spasial dapat dan seharusnya diajarkan di semua jenjang dalam sistem pendidikan. Tujuannya agar setiap warga memiliki spatial literacy yang baik. National Research Council (2006) menunjuk beberapa ciri dari masyarakat yang memiliki spatial literacy yang baik, yaitu:

- Memiliki kebiasaan berpikir spasialmereka tahu kemana, kapan, bagaimana dan mengapa berpikir secara spasial;

- Menerapkan berpikir spasial dengan pengetahuan yang memadai atau dengan dasar pengetahuan mereka memiliki pengetahuan yang luas dan dalam tentang konsep spasialdan representasi spasial, mampu mengontrol penjelasan spasial dengan mengunakan berbagai cara berpikir spasial, memiliki kemampuan yang baik untuk menggunakan sistem pendukung dan teknologi berbasis spasial.

- Mengadopsi pendirian atau sikap mental yang kritis untuk berpikir spasial - mereka mengevaluasi kualitas data spasial berdasarkan sumbernya, akurasi, dan realibilitas,; mereka dapat menggunakan data spasial untuk mengkonstruk, mengartikulasi, dan mempertahankan alasan atau pandangan dalam memecahkan masalah dan menjawab pertanyaan.; dan mereka dapat mengevalusai validitas argument berdasarkan informasi spasial.

\section{Peran SIG dalam Pengembangan Berpikir Spasial}

$\begin{array}{ccr}\text { Kersky } & (2008) & \text { menyatakan } \\ \text { efektivitas } & \text { pendidikan } & \text { kebumian }\end{array}$ seharusnya focus pada berpikir spasial sehingga siswa memahami pola spasial, keterkaitan, dan hubungan. Befikir spasial dapat didukung oleh sistem pendukung yang memiliki kemampuan untuk menunjukkan berbagai jenis permasalahan, menggunakan berbagai tipe dan jumlah data dan memerlukan perbedaan level kemampuan dan pengalaman. Sistem pendukung untuk berpikir spasial harus memungkinkan spasialisasi data, memfasilitasi visualisasi pekerjaan dan hasil akhir serta memiliki beragam fungsi seperti transformasi, operasi, dan analisis. Kemampuan tersebut dimiliki oleh sebuah 
system pendukung bernama Sistem Informasi Geografis.

SIG merupakan sistem pendukung yang handal untuk berpikir spasial. SIG dapat berperan sebagai alat untuk mendukung berpikir spasial. Di dalamnya merupakan integrasi dari hardware dan software serta prosedur yang memiliki kemampuan untuk collecting data, manajemen, manipulasi dan analisis, pemodelan dan menampilkan data yang memiliki referensi ruang. Peterson et al (2003) menyebutkan bahwa, " the use of GIS in geography education developed students spatial thinking skills and supported the overall geography teaching at the upper secondary school level.

Downs and DeSouza (Marsh, 2007) mengemukakan bahwa SIG merupakan alat yang sangat berguna dalam hubungannya dengan pendidikan sebagai sistem pendukung (support system) untuk berpikir spasial. Menurutnya kunci untuk berpikir spasial terdiri atas tiga unsur yaitu sifat ruang, alat atau metode untuk merepresentasikan informasi spasial, dan proses untuk memberi alasan. Dengan memahami arti dari ruang, misalnya ukuran, urutan/kesinambungan, kedekatan, keterpisahan dan lain-lain, maka dapat menjadi sarana untuk merumuskan masalah, menemukan jawaban dan menyampaikan solusi.

Efek dari pembelajaran berbasis SIG terhadap keterampilan spasial telah diteliti oleh Lee dan Bernarz (2009). Tes kemampuan atau keterampilan spasial digunakan untuk menguji efek pembelajaran dengan menggunakan SIG terhadap kemampuan spasial. Walaupun dilakukan pada mahasiswa sebuah perguruan tinggi, namun setidaknya dapat memberikan gambaran adanya hubungan antara kegiatan dan pengalaman menggunakan SIG dengan kemampuan berpikir spasialnya. Skor hasil test kemampuan spasial antara sebelum dan setelah kegiatan menunjukkan perubahan yang signifikan.
Pada jenjang sekolah menengah, Kersky (2000) melaporkan bahwa sekolah yang siswanya menggunakan SIG memiliki skor lebih tinggi dalam tes analisis spasial dibandingkan dengan siswa yang menggunakan metode tradisional. Kelompok siswa yang menggunakan SIG menunjukkan kemampuan lebih tinggi dalam mengidentifikasi, mensintesis, dan mendeskripsikan pola-pola manusia dan fisik.

Bednarz (2004) mengemukakan salah satu alasan pentingnya SIG masuk dalam kurikulum sekolah yaitu mampu meningkatkan kualitas pembelajaran geografi. Bagi guru geografi, kemampuan tersebut lebih mengarah pada kemampuan berpikir spasial. Tabel 1 kolom bagian kiri menunjukkkan aspek-aspek berpikir spasial yang banyak dikembangkan di kelas geografi, khususnya di Amerika Serikat. Paralel dengan itu, pada kolom bagian kanan ditunjukkan proses yang digunakan oleh individu untuk membangun peta kognitif mereka. Peta kognitif merupakan pengetahuan yang tersimpan pada individu tetang lingkungan yang dikelola sebagai model internal tentang dunia. Peta kognitif merupakan dasar penentuan keputusan spasial maupun non spasial. Peta kognitif merupakan hasil dari interaksi data relasional spasial, proses berpikir spasial, dan atribut lingkungan yang disaring melalui persepsi, kepercayaan, nilai dan sikap. Disarankan bahwa peta kognitif merupakan SIG yang terinternalisasi.

$$
\text { Selanjutnya, Bernarz }
$$

mengemukakan bahwa alasan edukatif masuknya SIG dalam pendidikan adalah untuk membantu siswa belajar geografi dengan mempraktekkan berpikir spasial. Dengan mempraktekkan SIG untuk menghasilkan peta maka kemampuan pemetaan kognitif peserta didik semakin dipertajam melalui aktivitas mengasosiasi dan mengkorelasi distribusi fenomena secara spasial. 
Tabel 1 Kemampuan Berpikir Spasial

\begin{tabular}{|c|c|}
\hline SPATIAL RELATIONS & $\begin{array}{l}\text { PROCESSES USED IN COGNITIVE } \\
\text { MAPPING AND GIS }\end{array}$ \\
\hline $\begin{array}{l}\text { 1. Abilities (skills) that recognize spatial } \\
\text { distribution and spatial patterns } \\
\text { 2. Identifying shapes } \\
\text { 3. Recalling and representing layouts } \\
\text { 4. Connecting locations } \\
\text { 5. Associating and correlating spatially } \\
\text { distributed phenomena } \\
\text { 6. Comprehending and using spatial } \\
\text { hierarchies } \\
\text { 7. Regionalizing } \\
\text { 8. Comprehending distance decay and } \\
\text { nearest neighbor effects in } \\
\text { distributions (buffering) } \\
\text { 9. Wayfinding in real world frames of } \\
\text { reference } \\
\text { 10. Imagining maps from verbal } \\
\text { descriptions } \\
\text { 11. Sketch mapping } \\
\text { 12. Comparing maps } \\
\text { 13. Overlaying and dissolving maps } \\
\text { (windowing) }\end{array}$ & $\begin{array}{l}\text { 1. Constructing gradients and surfaces } \\
\text { 2. Layering } \\
\text { 3. Regionalizing } \\
\text { 4. Decomposing } \\
\text { 5. Aggregating } \\
\text { 6. Correlating } \\
\text { 7. Evaluating regularity or randomness } \\
\text { 8. Associating } \\
\text { 9. Assessing similarity } \\
\text { 10. Forming hierarchies } \\
\text { 11. Assessing proximity (requires knowing } \\
\text { location) } \\
\text { 12. Measuring distance } \\
\text { 13. Measuring directions } \\
\text { 14. Defining shapes } \\
\text { 15. Defining patterns } \\
\text { 16. Determining cluster } \\
\text { 17. Determining dispersion }\end{array}$ \\
\hline
\end{tabular}

Sumber: Bednarz, 2004

Kajian efek SIG dalam pembelajaran tidak hanya sebatas keterampilan spasial tetapi pembelajaran geografi secara umum. Sejumlah hasil penelitian menunjukkan adanya kontribusi positif dari pembelajaran berbasis SIG. Hasil studi yang dilakukan oleh Ozgen (2009) menunjukkan adanya kontribusi positif yang signifikan secara statistik pada kelompok eksperimen. Skor pada kelompok eksperiman jauh melampaui skor pada kelompok kontrol. Keduanya menyatakan bahwa manfaat SIG dalam pembelajaran geografi tidak hanya dirasakan oleh siswa yang kuat dalam penguasaan komputer tetapi juga siswa yang lemah penguasaan komputernya.

Studi yang dilakukan Ozgen (2009) menunjukkan bahwa pengajaran geografi yang dibantu dengan SIG memberikan keuntungan bagi siswa berupa pemahaman yang lebih baik terhadap materi yang diajarkan dan memberikan kemudahan dalam mengakses data ilmiah yang sesuai dengan materi yang dipelajari. Dalam kasus migrasi penduduk yang dikajinya, Ozgen (2009) mengemukakan keuntungan metode pengajaran konstruktivis yang dibantu dengan menggunakan SIG, yaitu:

1. mengembangkan keterampilan geografis dan kemampuan menggunakan metode inkuiri.

2. dapat memadukan hasil kajian yang mereka buat dengan pengalaman ketika melakukan proses inkuiri

3. dapat meningkatkan pengetahuan geografis

4. dapat membangun keterkaitan antara aspek geografi fisik dan manusia 
Berdasarkan hasil survey yang dilakukan oleh Kerski (2000) terhadap 1520 guru sekolah menengah menunjukkan sebagian besar $(80 \%)$ setuju bahwa SIG memberikan keuntungan dalam pengajaran geografi, sekitar $1,8 \%$ menyatakan tidak memberikan keuntungan apapun juga, dan lainnya (10 $\%)$ tidak memberikan pendapat apapun. Secara lebih jelas, keuntungan dari pengajaran yang menggunakan SIG, dikemukakan pula oleh Ozgen (2009) berdasarkan hasil kajiannya dengan menggunakan sampel materi tentang migrasi penduduk, bahwa "In the event that a GIS-aided education model in geography teaching is used, students may draw very good benefits while comprehending the subject being taught and also be able to access scientific data relevant to the subjects they have learned with more ease".

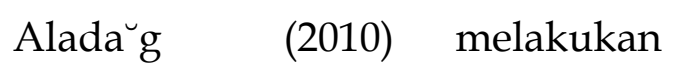

penelitian tentang efek SIG terhadap prestasi akademik dan motivasi di Turki. Hasilnya menunjukkan adanya perbedaan skor test yang signifikan antara kelas eksperimen dan kelas kontrol. Kelas eksperimen yang menggunakan pembelajaran berbasis SIG menunjukkan skor yang lebih tinggi disbanding kelas kontrol yang menggunakan pengajaran secara tradisional. Selain itu, motivasi belajar pada kelas eksperimen juga lebih tinggi secara statistik dibandingkan dengan motivasi belajar pada kelas kontrol.

$$
\text { Walaupun demikian, hasil }
$$
penelitian tentang efek positif tersebut masih terbatas dan tidak konsisten seperti yang dikemukakan oleh Lee dan Bernarz (2009), "Despite these assertions, research results that support the positive effects of GIS learning on spatial thinking are lacking or inconsistent". Komunitas penelitian pendidikan lingkungan dan geografi tidak mengetahui secara pasti kontribusi SIG dalam pembelajaran geografi dan lingkungan. Selanjutnya, dia juga mengatakan bahwa, "Several recent research studies have made it clear that little is known about the actual benefits and learning outcomes of GIS". Karena itu, sulit untuk menyatakan secara tegas menyatakan bahwa SIG pada jenjang pendidikan dasar dan menengah memiliki efek yang jelas dan positif terhadap perkembangan berpikir spasial, reasoning spasial dan pemahaman lingkungan sebagai tujuan sentral pembelajaran geografi.

\section{PENUTUP}

Kemampuan berpikir spasial sebagai inti dari pembelajaran geografi sangat dibantu dengan SIG. Setiap aktivitas atau langkah kerja dalam SIG sangat bersesuaian dengan aktivita berpikir spasial. Sistem pendukung berpikir spasial ini memang tidak selalu mudah dilaksanakan karena berbagai keterbatasan yang ada. Namun, sistem pendukung ini memberi harapan sekaligus tantangan bagi para pendidik geografi agar geografi semakin menarik dan bermakna bagi siswa untuk kehidupannya saat ini dan kelak ketika mereka dewasa.

\section{DAFTAR PUSTAKA}

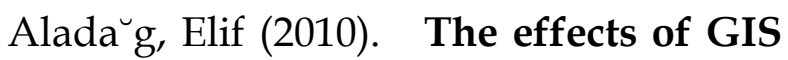
on students' academic achievement and motivation in seventh-grade social studies lessons in Turkey. [Online] ISSN: 1038-2046 print / 17477611 online C_2010 Taylor \& Francis. Tersedia:

http://web.ebscohost.com/ehost/pdf viewer/ pdfviewer [26 Juli 2011]

Bednarz, S.W.(2004) Geographic Information Systems: A Tool to Support Geography and Environmental Education? GeoJournal 60: 191-199, 2004. Tersedia: http://users.utu.fi/vijoke/Kirjallisuu sGIS\% 20tool\%20to\%20support \%20geo graphy.pdf (02 Februari 2012) 
Kerski, Joseph J. (2000) The Implementation and Effectiveness of Geographic Information Systems Technology and Methods in Secondary Education. University of Colorado

Kerski, Joseph J. (2008). The role of GIS in Digital Earth education. International Journal of Digital Earth, Vol. 1, No. 4, December 2008. Tersedia:

http:// web.ebscohost.com/ehost/pdf viewer/ pdfviewer [02 Agustus 2011)

Lee, Jongwoon And Robert Berdnarz (2009) Effect Of GIS Learning On Spatial Thinking. Journal of Geography in Higher Education, Vol. 33, No. 2, 183-198, tersedia: http://web.ebscohost.com ehost/pdfviewer/pdfviewer (29 Juli 2011)

Marsh, Meredith, Reginald Golledge, and Sarah E. Battersby (2007). Geospatial Concept Understanding and Recognition in G6-College Students: A Preliminary Argument for Minimal GIS. Annals of the Association of American Geographers, 97(4), 2007, pp. 696-712. Tersedia: http://web.ebscohost.com ehost/pdfviewer/pdfviewer [02 Agustus 2011]

National Research Council (2006) Learning to Think Spatially: GIS as a Support System in the $\mathrm{K}-12$ Curriculum (Washington, DC: National Academies Press). 